\title{
Introducing English in Early Year's Children through Dancing and Singing
}

\author{
Sari Purnamawati ${ }^{1, *}$ Heru Djoko Walojo ${ }^{1}$ \\ ${ }^{I}$ School Center of Early Childhood and Community Education (PP PAUD DIKMAS) Central Java, Semarang, Indonesia \\ *Corresponding author. Email: sariekurnia78@gmail.com
}

\begin{abstract}
Introducing English to early childhood has been done by a lot of Early Childhood Education institutions. Yet, the teachers lack the media and method to introduce English to the children. Teachers do not have many options of method and media. They use the same printed media repeatedly which makes the teaching process becoming dull and bores the children. Teachers need other alternative media to introduce English to the children in a fun way. Children learn through playing, therefore teachers need to provide interesting method and media to teach. By using dancing and singing, children will not only become interested in the learning process but also received adequate stimulation for their visual, auditory, and motor aspect. Such dancing and singing will be more practical if stored in the compact disk (CD). The aim of the research is to provide a guide for teacher to use and implement the dancing and singing media; to provide an alternative media in introducing English to the children; and to provide an interesting and fun learning experience for the children. Through the three themes of dancing and singing which is close to the children daily life, the teachers are able to develop or create various activities and media in introducing English to children. It also lengthens the range of concentration of the children. As a result, the children's vocabulary is enhancing.
\end{abstract}

Keywords: Introducing English, CD Media, dancing, singing

\section{INTRODUCTION}

Global competition requires us to improve our quality in human resources and able to master the international language, English. It is the language the children need in their academic and social skills.

Education First (EF) announced the results of the global survey 'English Proficiency Index' (EF EPI) in Jakarta, Thursday (12/08/2016) where Indonesia had a score of 52.91 in the 32nd position out of 72 countries surveyed. Indonesia achieved a lower score than Vietnam, which ranked 31 st in the 'middle level'. Seeing these data and in line with the enactment of the ASEAN economic community (AEC), Indonesia's position in the competition of the ASEAN community is becoming less competitive in terms of mastering English. The right step to start is to introduce English as early as possible to children. This is in line with the policies of the Direktur Jendral PAUD dan Dikmas (2002) which makes the introduction of English for young children one of the priority programs and policies in 2017.

The most sensitive period for language in a person's life is between the ages of two to seven years. All aspects of language must be introduced to children before this sensitive period ends. During this sensitive period it is very important to introduce good and correct language, because this skill is very useful for communicating with the environment (Montessori, 1991). Based on this theory, it is appropriate if English is introduced to children as early as possible. Considering that English is the first foreign language in Indonesia, the learning process must be carried out in stages. The choice of material that is appropriate for the age of the child and is also effective for the cognitive development of the child's language and a pleasant learning situation should be a major concern in the success of a learning process.

Based on the results of exploratory studies conducted in March 2017 by the development team of PP PAUD and Dikmas Central Java on several ECE institutions it is known that: 1) There is no specific day or schedule to introduce English, 2) The introduction of English is limited to singing, counting and clapping, 3) Institutions do not have adequate and interesting media in introducing English to children, 4) Educators have difficulty finding media as well as teaching materials as references, guidelines or tutorials for introducing English to children.

\section{INTRODUCING ENGLISH THROUGH DANCING AND SINGING}

\subsection{Dancing and Singing}

The methods and techniques used in introducing English to children should be selected and adjusted to the abilities to be achieved. The professionalism of an educator in developing and utilizing these methods and techniques is needed so that the learning process can run better. Teaching methods and processes in communicative contexts include 
the context of social situations, culture, games, singing and music, reading of stories, experiences of arts, crafts and prioritizing physical movements are very appropriate and effective methods if used in the process of learning English especially for early childhood.

Furthermore, according to Matondang (2005, p. 134) music and motion are very successful methods if used in the process of learning English especially for young children. Using music and movement as an approach in the process of learning English and presenting it in an interesting and enjoyable way in a process of teaching and learning, can help children to be happier and more active in learning and make it easier for children to understand a teaching material. Because in carrying out learning activities children are invited to perform and demonstrate a movement that is in accordance with the meaning of the song being sung. So the motion and song is a very enjoyable activity for children and can also be used as a motivator in the process of learning English in early childhood.

Music and movement plays an important role in the development process of a child. Songscan enrich the spiritual life and provide a balance of life for children. Through music, humans can express the thoughts and feelings of their hearts and can control their emotional aspects. Singing is part of the music. The song functions as a tool to devote thoughts and feelings to communicate.

\subsection{Specifications Dancing and Singing CD}

According to Riyana (2007) learning CD media is a medium that presents audio and visuals that contain learning messages containing concepts, principles, procedures, theory to help the understanding of learning material. Tutorial CD is a series of live images that is displayed by a teacher that contains learning messages to help understand an instructional material as guidance or additional teaching material to a small group of students.

As it is known that there are three types of learning styles for children, namely visual, auditory learning styles and kinesthetic learning styles. Learning CD media can accommodate or provide stimulus to the three types of children's learning styles because in $\mathrm{CD}$ media there are three elements, namely sound, vision and movement.

The Dancing and Singing Tutorial CD is a learning media $\mathrm{CD}$ containing examples of dancing and songs in English, consisting of four themes namely my body, my family, my daily activity and my environment; where users can only not get information but also guidance in introducing English to early childhood.

English learning activities carried out through dancing and singing in the tutorial $\mathrm{CD}$ will provide a fun learning experience for children. If children engage in fun activities in learning English through dancing and singing so then the children will tend to repeat the activity. Things that are done repeatedly will change their habituation and behavior.

\subsection{Specifications Dancing and Singing $C D$}

The Dancing and Singing Tutorial CD is intended for early childhood educators as a medium and teaching material for introducing English to early childhood through movement and song.

It has two menus, namely:

1) Let's sing and dance: This menu is a tutorial for inviting children to sing and dance according to the song and move they see on the show.

2) Let's say: This menu is a tutorial to invite children to imitate words or sentences with a predetermined theme.

The movements and songs contained in this tutorial CD contain four themes, namely:

1) My body: Theme for introducing limbs.

2) My family: Theme for introducing family members.

3) My daily activity: Theme about daily activities carried out by children starting from waking up.

4) My environment: Theme for introduction of the environment closest to children.

The english language introductory tutorial CD model for early childhood through motion and songs is also equipped with various guidelines and teaching materials as a guide for educators to implement the introduction of english in early childhood.

\section{IMPLEMENTATION OF THE CD}

The stages of implementing the $\mathrm{CD}$ are as follows:

\subsection{Opening}

At the opening activity, the teacher gives an explanation to children on what activities will be carried out that day. Teachers must first study the CD and its devices so that they can create appropriate opening activities. By studying the $\mathrm{CD}$ beforehand, it means that they must also learn the writing and pronunciation of words that will be introduced correctly. Teachers can start introducing words in learning themes that will be introduced to English. For the second and subsequent meetings teachers can start activities by recalling activities and words that were introduced at the previous meeting. Activities can be done by clapping, counting and spelling letters in English.

\subsection{Core Activity}

The activity began with Let's Sing and Dance. Teachers and children begin to watch the $\mathrm{CD}$ to imitate movements and listen to the lyrics of the song. This activity can be repeated two to three times, or according to the wishes of the child. One teacher can stand in front of the children, facing the screen or monitor to give children an example of the movement. The other can stand behind the children so that when there is a circular motion the children can still imitate the movements of the teacher. In this activity it is possible 
if the teacher also sings without music so that the pronunciation of the lyrics can be heard clearly.

After singing and dancing, the activity continued with Let's Say. This activity requires teachers to learn the English words that will be introduced beforehand, so that they can give the correct examples of pronunciation to the children. The teachers provide examples of pronunciation of words that are correct and clear, then can be followed by the use of these words in simple sentences such as those used in the lyrics of the theme song being studied.

Example: eyes, I can see with my eyes

The next activity is Let's Play which is also an evaluation tool for teachers on the development of children's vocabulary mastery. In this activity, educators play with children to find out the extent of their mastery of vocabulary on the themes they have just learned. The children does not feel assessed because the evaluation is carried out through play.

\subsection{Closing}

In this activity, the teachers provide a recalling session with the children about their learning experience. Teachers can explore the extent to whether the children understand the learning experiences and then provide reinforcement to children. The flow of activities at this stage are: cleaning up, recalling, messages and praying.

\subsection{Evaluation}

Evaluation is aimed to see the achievement of the development of English abilities of the children that can be conducted through observation and assessment of the performance. When the children do the activity, the teacher observes everything that is done by the child which areattitude, behaviour, language and expression of the child. The teacher takes notes as evidence as well as a reminder of everything that they observes. The technique used in recording is a checklist with four scales as follows:

1) BB: Not yet Developed, if the child perform some tasks with guidance or exemplified by the teacher

2) MB: Start Developing, if the children do some tasks if they are reminded or assisted by the teacher.

3) BSH: Develops as expected, meaning that the child can do it independently and consistently without having to be reminded or exemplified by the teacher.

4) BSB: Well developed, meaning that if the child is able to do it independently and can help his friend who has not achieved the ability in accordance with the expected indicators.

\section{RESULT OF THE STUDY}

The research results in this section present an analysis of the effectiveness of the Tutorial CD includes: understanding and being able to speak receptive language, understanding and being able to expressive language, and getting to know early literacy. There are 53 respondents from 3 early childhood institutions in Central Java. Data processing was performed using SPSS, in which the following results were obtained.

\subsection{Results}

\subsubsection{Receptive language}

Before being given a tutorial $\mathrm{CD}$, the ability to recognize receptive language in early childhood in the introduction of English, in the Start Developing category (MB) is 39 children $(73.6 \%)$. While there are 13 children in the Not Yet Developed category (BB). After being given a tutorial CD, the ability to recognize receptive language in early childhood in the introduction of English, mostly in the Develops as Expected category (BSH) have a total of 48 children $(90.6 \%)$. While 5 other children are still in the Start Developing category (MB).

Before being given the Tutorial $\mathrm{CD}$, the average value of the respondents' receptive language recognition ability was 5.72. Then, it increased to 7.96 after being given the tutorial CD.

Based on the Wilcoxon test, the calculated $\mathrm{Z}$ value was 6,432 with a p-value of 0,000 . Because of the p-value of $0,000<\square(0.05)$, it was concluded that there was a significant difference in the ability to recognize Receptive language in early childhood before and after given the Tutorial CD. It also shows that providing Tutorial CDs can effectively improve the ability to recognize Receptive language in early childhood. The result of the improvement can be seen where before giving the Tutorial CD, the average value of the ability to recognize the respondent's language was 5.72, where it increased to 7.96 after being given the Tutorial CD for 6 days of meeting.

\subsubsection{Expressive language}

Before being given a tutorial $\mathrm{CD}$, the ability to recognize expressive language in early childhood in the Start Developing category (MB) isa total of 45 children $(84.9 \%)$, while there are 5 children in the Not Yet Developed category $(\mathrm{BB})$. After being given a tutorial $\mathrm{CD}$, the ability to recognize expressive language, mostly in the Develops as expected category (BSH), the number is 47 children $(88.7 \%)$, while there are 5 other children in the Well developed category (BSB).

Before being given the Tutorial $\mathrm{CD}$, the average value of the ability to recognize the expressive language of respondents was 5.89. Then, it increased to 9.28 after being given the tutorial $\mathrm{CD}$.

Based on the Wilcoxon test, the calculated $\mathrm{Z}$ value was 6.866 with a p-value of 0,000 . Because of the $p$-value of $0,000<\square(0.05)$, it was concluded that there was a significant difference in the ability to recognize expressive 
language in early childhood before and after given the Tutorial CD. It also shows that giving the Tutorial CDs can effectively improve the ability to recognize expressive language. The increase occurred where before giving the CD Tutorial the average value of the ability to recognize the expressive language of the respondents was 5.89 increased to 9.28 after giving the Tutorial $\mathrm{CD}$ for 6 days of meeting.

\subsubsection{Early literacy}

Before being given a tutorial $\mathrm{CD}$, early literacy skills in early childhood in the introduction of English, is in the Start Developing category (MB), where it consists of 44 children $(83.0 \%)$. after being given a tutorial CD, early literacy skills in early childhood is mostly in the Well-developed category (BSB), totaling 28 children (52.8\%). While 25 children $(47.2 \%)$ are in the Develops as expected (BSH).

Before being given a Tutorial $\mathrm{CD}$, the average value of the respondent's early literacy ability was 11.51 . Then, it increased to 16.49 after being given a tutorial CD.

Based on the Wilcoxon test, the calculated $\mathrm{Z}$ value was 6.424 with a p-value of 0,000 . Because the p-value of 0,000 $<\square(0.05)$, it was concluded that there was a significant difference in early literacy abilities in early childhood in the introduction of English before and after the implementation of the Tutorial $\mathrm{CD}$ through dancing and singing. It also shows that giving CD Tutorials can effectively improve early literacy skills in early childhood in the introduction of English. The increase occurred where before providing the Tutorial CD the average value of the initial literacy ability of respondents was 11.51 , it increased to 16.49 after the Tutorial CD was provided for 6 days of meeting.

\section{CONCLUSION AND RECOMMENDATION}

\subsection{Conclusion}

Based on the results it can be concluded that introducing English through Dancing and Singing CD is an effective method used to improve children's language development and achievements as measured in the basic competencies of attitude, knowledge and skills.

\subsection{Recommendation}

1) This model will be more effective if in the "let's play" segment teachers can provide a variety of play that is quite varied according to the theme and number of children.

2) For the users, in this case the educators or teachers should always provide reinforcement in each segment of activities for example by repeating songs on a CD to be sung together without music so as to speed up children's memorization and understanding of the words in the songs.
3) For model developers or researchers who are interested in doing the same research, it is recommended to create and apply different themes and song movements.

\section{REFERENCES}

Direktur Jenderal PAUD \& Dikmas. (2002). Acuan menu pembelajaran pendidikan anak usia dini. Jakarta: Kementerian Pendidikan dan Kebudayaan Republik Indonesia

Matondang, E. M. (2005). Menumbuhkan minat belajar bahasa inggris anak usia dini melalui lagu dan gerak. Jakarta: Jurnal Pendidikan Penabur.

Montessori, M. (1991). Schule des

kindes.(L'autoeducazione nelle scuole elementari). Montessori-Erziehung in der Grundschule. Hrsg., eingel v. Paul Oswald, Günter Schulz-Benesch.(4. Aufl.). Herder.

Riyana, C. (2007). Pedoman pengembangan media video. Jakarta: P3AI UPI. 